\title{
Physiological Studies on Apricot Trees Fertilization Grown in Ismailia Governorate 2- effect of Mineral (npk), Organic (compost) Fertilizers and Some Soil bio-stimulants on Growth and Nutritional Status of "Canino" Apricot Trees
}

\author{
M. M. Sharaf*, F. M. Abed-Elatif*, Kh. A. Bakry*, A. F. El- \\ Ramah $^{* *}$ and N. A. Abdou** \\ *Faculty of Agriculture, Benha University, Benha and \\ **Horticulture Research Institute, Agricultural Research \\ Centre, Cairo, Egypt.
}

\begin{abstract}
7 HE EFFECT of mineral (NPK) soil application either alone or in combination with organic (compost) and some soil bio-stimulants (EM, bio-fertilizer, humic acid and compost tea) on increment percentage in trunk diameter (ITD \%), average length and thickness of new shoots $(\mathrm{cm})$, average number of leaves per shoot, leaf area and its dry weight, leaf photosynthetic pigments and leaf mineral content of apricot "Canino" cv. budded on local apricot rootstock grown at ElKassasien Horti. Res. Sta., Ismailia Governorate during two successive seasons of $(2010 \& 2011)$ and $(2011 \& 2012)$. The obtained results revealed that all vegetative growth parameters under study except organic fertilizer (compost) at $100 \%$ level resulted in significant increase in trunk diameter (ITD \%), average length and thickness of new shoots $(\mathrm{cm})$, average number of leaves per shoot and leaf area and its dry weight during both seasons of study. The same treatments increased, also, leaf nutrient contents of $\mathrm{N}, \mathrm{P}, \mathrm{K}, \mathrm{Ca}, \mathrm{Mg}, \mathrm{Zn}, \mathrm{Fe}$ and $\mathrm{Mn}$ as well as leaf photosynthetic pigments (chlorophyll a, b and carotein). It could be concluded that all investigated NPK soil application in mineral form, organic (compost) fertilizers and some soil stimulants results in significant effect, however, the fertilization with mineral (NPK) at $100 \%$ level (T1) and mineral NPK in mineral form at $50 \%$ level + organic (compost) fertilizer at $50 \%$ level coupled with all tested soil stimulants (T13) were the most effective treatments for increasing vegetative growth parameters and leaf nutrient contents of "Canino" cv. Apricot trees.
\end{abstract}

Apricot (Prunus armeniaca L.) is a member of the stone fruits of the family Rosaceae, sub family Prunoidea. The fruit is classified as a drupe and distinguished by a double sigmoid curve with rapid growth during cell division, followed by a period of slow or ceased growth during pit hardening, and then a period of rapid cell enlargement.

Organic fertilizers improve the physical, chemical and biological properties of all soil types, adjusting soil $\mathrm{pH}$, increasing nutrient solubility and production of the plants (Zhou et al., 2001). The addition of organic manure to the soil 
encourages proliferation of soil micro organisms, increases microbial population and activity of microbial enzymes, viz. dehydrogenase, urease and nitrogenase (Abou-Hussein et al., 2002). Some investigators studied the effect of organic manure application as compared with chemical fertilizer on different fruit crops (Stino et al., 2009) on yang "Canino" apricot, (Mohamed et al., 2010) on pear, (Fayed, 2005 b) on apple, (Fayed, 2005a) on peach. They reported that, under organic systems, soil biotic life increased as a result of the plant synthesis of more vitamins and sugar. Moreover, the addition of organic fertilizer is necessary for the best growth, greater yield and fruit quality when compared with mineral fertilizers.

Bio-fertilizers are the most important for plant production and soil as they play an important role in increasing vegetative growth, yield and fruit quality (Kabeel et al., 2005 and Shddad et al., 2005) on "Canino" apricot, (Mansour, 1998 and Fayed, 2005b) on apple. Also, Hassan and Abou- Rayya (2003) showed that all bio-fertilizers (Nitrobein, Phosphorein, Biogein and Rhizobacterien at 10, 20, $30 \mathrm{~g}$ per tree) were effective in improving nutritional status of Anna apple trees.

Humic acid (polymeric polyhydroxy acid) was the most significant component of organic substances in aquatic system. Humic acid is highly beneficial to both plants and soil, increase microbial and mycorrizal activity, a plant growth bio-stimulant, an effective soil enhancer, promote nutrient uptake (chelating agent) and increase crops yield (Fathi et al., 2002 and Fawzia Eissa et al., 2007) on apricot seedlings, apple, and peach.

Effective microorganisms (EM) technology was developed by Dr. Teuro Higa in 1970's at the University of Ryukyus, Okinawa, Japan. Effective microorganisms culture consists of co-existing beneficial microorganisms, the main being the species of photosynthetic bacteria, Rhodopseudomonas plastris and Rhodobacter sphacrodes, lactobacilli such as Lactobacillus plantarum, L. casei and Streptococcus lactis, yeasts (Saccharomyces spp) and Actinomycetes (Strptomyces spp.) which improve crop growth and yield by increasing photosynthesis, producing bioactive substances such as hormones and enzymes, controlling soil diseases and accelerating decomposition of lignin materials in the soil (Higa, 2000, Hussain et al., 2002).

Compost tea, in modern terminology is a compost extract, plant extracts, liquid manures and compost teas can be further understood in the context of their influences on the rhizosphere and phyllosphere. Also, manure and compost tea production is a brewing process that extracts microorganisms from compost or manure followed by microbial growth and multiplication including beneficial bacteria, fungi and protozoa (Ingham, 2005).

The main objective of this study, is to carry out a comparison between using organic manure (compost) or inorganic (NPK) fertilizer or its combination as a source of soil fertilization in the presence of some soil stimulants in order to Egypt. J. Hort. Vol. 42, No.1 (2015) 
know which fertilizer source more beneficial for vegetative growth and leaf nutrient contents of apricot trees "Canino" cv. grown under Ismailia governorate conditions.

\section{Material and Methods}

This investigation was carried out during 2010 and 2012 growing seasons on ten - year - old apricot trees "Canino" cv. budded on local apricot rootstock planted at $5 \times 5 \mathrm{~m}$ apart (168 trees/ feddan) in sandy soil under drip irrigation system and grown at El-Kassasien Hort. Res. Sta., Ismailia Governorate. Fifty two fruitful apricot trees "Canino" cv. were carefully selected. These trees were similar in their growth vigor, size, shape and diseases - free as well as they received the same culture management. Mechanical and chemical analysis of orchard soil have been carried out prior to the first season according to the methods described by Piper (1947) and Jackson (1967) as shown in Table 1.

TABLE 1. Physical and chemical analysis of the experimental orchard soil

\begin{tabular}{|l|c|c|c|}
\hline \multicolumn{2}{|l|}{ Physical characteristics \% } & \multicolumn{2}{c|}{ Chemical characteristics } \\
\hline Field capacity & 11.77 & $\mathrm{CaCO}_{3} \%$ & 12.25 \\
\hline Available water & 1.55 & Organic matter \% & 0.08 \\
\hline Wilting point & 4.20 & $\mathrm{pH}$ & 7.5 \\
\hline Coarse sand & 67.08 & $\mathrm{EC}(\mathrm{ds} / \mathrm{m})$ & 2.14 \\
\hline Fine sand & 9.5 & $\mathrm{Ca}(\mathrm{mg} / 100 \mathrm{~g})$ & 0.14 \\
\hline Silt & 0.7 & $\mathrm{Na}(\mathrm{mg} / 100 \mathrm{~g})$ & 0.34 \\
\hline Clay & 5.2 & $\mathrm{~K}(\mathrm{mg} / 100 \mathrm{~g})$ & 0.16 \\
\hline Texture class & Sandy & $\mathrm{Cl}(\mathrm{mg} / 100 \mathrm{~g})$ & 0.30 \\
\hline
\end{tabular}

Rate and method of application of the investigated materials is briefly summarized as follows:

Rate and application method of organic manure (compost)

Two rates of organic fertilizers were used $100 \% \quad(22 \mathrm{~kg}$ compost $+2.123 \mathrm{~kg}$ of feldspar natural rocks per tree) the abovementioned rate release 450,100 and $500 \mathrm{~g}$ of $\mathrm{N}, \mathrm{P}$ and $\mathrm{K}$ per tree respectively, which were equivalent to the same quantities delivered by using NPK as chemical fertilizers that were recommended by the Ministry of Agriculture. The second rate $50 \%(11 \mathrm{~kg}$ compost $+1.0615 \mathrm{~kg}$ of feldspar natural rocks per tree) which release 225,50 and $250 \mathrm{~g}$ of N, P and K per tree. Moreover, in early December of both seasons of study one trench $(50 \times 50 \times 50 \mathrm{~cm})$ was excavated on one side of the tree, then the given amount of both compost and feldspar as well as apart of surface soil was mixed together and added to the chuck hole followed by irrigation.

The chemical analysis of organic manure (compost) and some chemical components of feldspar natural rocks are shown in Tables 2 and 3 respectively. 
TABLE 2. Chemical analysis of organic manure (compost) and Chemical composition of Feldspar nature rock.

\begin{tabular}{|c|c|c|c|}
\hline \multicolumn{2}{|c|}{ Parameter } & \multicolumn{2}{|c|}{ Mature form compost } \\
\hline \multicolumn{2}{|c|}{ Cubic meter weight } & \multicolumn{2}{|c|}{$450 \mathrm{~kg}$} \\
\hline \multicolumn{2}{|l|}{ Moisture \% } & \multicolumn{2}{|c|}{26} \\
\hline \multicolumn{2}{|c|}{ Organic matter $\%$} & \multicolumn{2}{|c|}{51} \\
\hline \multicolumn{2}{|l|}{$\mathrm{pH}(1: 10)$} & \multicolumn{2}{|c|}{8.3} \\
\hline \multicolumn{2}{|l|}{$\mathrm{EC}(\mathrm{ds} / \mathrm{m})$} & \multicolumn{2}{|c|}{3.1} \\
\hline \multicolumn{2}{|l|}{$\mathrm{C} / \mathrm{N}$ ratio } & \multicolumn{2}{|c|}{15.78} \\
\hline \multicolumn{2}{|l|}{ Total N\% } & \multicolumn{2}{|c|}{2.1} \\
\hline \multicolumn{2}{|l|}{ Total P\% } & \multicolumn{2}{|c|}{1.5} \\
\hline \multicolumn{2}{|l|}{ Total K\% } & \multicolumn{2}{|c|}{1.26} \\
\hline \multicolumn{2}{|l|}{ Total $\mathrm{Ca} \%$} & \multicolumn{2}{|c|}{1.95} \\
\hline \multicolumn{2}{|c|}{ Total $\mathrm{Mg} \%$} & \multicolumn{2}{|c|}{0.96} \\
\hline \multicolumn{2}{|c|}{ Total Fe (ppm) } & \multicolumn{2}{|c|}{1025} \\
\hline \multicolumn{2}{|c|}{ Total Mn (ppm) } & \multicolumn{2}{|c|}{115} \\
\hline \multicolumn{2}{|c|}{ Total Zn (ppm) } & \multicolumn{2}{|c|}{28} \\
\hline \multicolumn{2}{|c|}{ Total Cu (ppm) } & \multicolumn{2}{|c|}{180} \\
\hline Feldspar & Component (\%) & Feldspar & Component (\%) \\
\hline L.O.I & 0.72 & $\mathrm{~K}_{2} \mathrm{O}$ & 10.6 \\
\hline $\mathrm{SiO}_{2}$ & 71.94 & $\mathrm{Na}_{2} \mathrm{O}$ & 1.94 \\
\hline $\mathrm{AlO}_{2}$ & 13.92 & $\mathrm{TiO}_{2}$ & 0.01 \\
\hline $\mathrm{FeO}_{2}$ & 0.09 & $\mathrm{MnO}_{2}$ & 0.01 \\
\hline $\mathrm{CaO}$ & 0.32 & $\mathrm{P}_{2} \mathrm{O}_{2}$ & 0.04 \\
\hline $\mathrm{MgO}$ & 0.08 & $\mathrm{Cl}$ & 0.03 \\
\hline
\end{tabular}

Rate and application method of bio-fertilizers

Four types of bio-fertilizers were investigated throughout this study:

- Phosphorene: is a commercial phosphor bio- fertilizer which contains some active bacterial strains (Arbuscular mycrohiza and silicate bacteria) that play an important nutritional role in $\mathrm{P}$ uptake through changing the unavailable phosphate from (insoluble tri-Calcium phosphate) into available soluble one (mono- Calcium phosphate).

- Nitrobein: is a commercial nitrogenous bio-fertilizer that contains special bacteria (Azotobacter choroccocum) having the ability for free nitrogen fixation.

- Potassein: is a commercial potassium bio-fertilizer contains special bacteria (Bacillus pasteurii) which releasing the potassium in available form.

Egypt. J. Hort. Vol. 42, No.1 (2015) 
Each of the three abovementioned bio-fertilizer was added as soil application (15 cm soil depth) to the wetted compost in three equal doses in December, March, and June at the rate of $30 \mathrm{~g} /$ tree $/$ dose.

Effective Microorganisms (EM): EM was used in a solution, it was added to the wetted compost as soil application during the two studied seasons, the biofertilizer (EM) was added in three equal doses at $250 \mathrm{ml} /$ tree/dose in the first week of December, March, and June while the irrigation was conducted after all application.

\section{The preparation, rate and application date of compost tea:}

Compost tea was added as soil application in three equal doses each at 2 liters/tree/dose in December, March, and June. Compost tea was made by hand method (10kg compost +100 litter clean water + Glucose).Teas are actively brewed with microbial food and catalyst sources added to the solution, and a pump bubbles to aerate the solution, and subsequently supplying plenty of muchneeded oxygen. The aim of the brewing process is to extract beneficial microbes from the compost itself, followed by growing these populations of microbes during the 24- to 36-hours. Microbial population and chemical analysis of organic compost tea are shown in Tables 4 and 5 respectively.

TABLE 3. Microbial population of organic compost tea.

\begin{tabular}{|l|l|}
\hline Bacterial Plate count $(\mathrm{CFU} / \mathrm{ml})$ & $7.1 \times 10^{7}$ \\
\hline Bacterial Direct count $(\mathrm{cell} / \mathrm{ml})$ & $6.4 \times 10^{8}$ \\
\hline Spore forming bacteria $(\mathrm{CFU} / \mathrm{ml})$ & $7 \times 10^{4}$ \\
\hline Total fungi $(\mathrm{CFU} / \mathrm{ml})$ & $1.1 \times 10^{4}$ \\
\hline Actinomycetes $(\mathrm{CFU} / \mathrm{ml})$ & $2.8 \times 10^{5}$ \\
\hline
\end{tabular}

$(\mathrm{CFU})=$ Colony Forming Unit.

TABLE 4. Chemical analysis of the organic compost tea .

\begin{tabular}{|l|c|}
\hline Parameter & Compost tea (extract) \\
\hline Cubic meter weight & - \\
\hline Moisture\% & - \\
\hline Organic matter\% & - \\
\hline $\mathrm{pH}(1: 10)$ & 7.5 \\
\hline $\mathrm{EC}(\mathrm{ds} / \mathrm{m})$ & 4.59 \\
\hline $\mathrm{C} / \mathrm{N} \mathrm{ratio}$ & - \\
\hline Total $\mathrm{N} \%$ & $280 \mathrm{ppm}$ \\
\hline Total $\mathrm{P} \%$ & $30 \mathrm{ppm}$ \\
\hline Total $\mathrm{K} \%$ & $206 \mathrm{ppm}$ \\
\hline Total $\mathrm{Ca} \%$ & $87 \mathrm{ppm}$ \\
\hline Total $\mathrm{Mg} \%$ & $116 \mathrm{ppm}$ \\
\hline Total $\mathrm{Fe}(\mathrm{ppm})$ & $66 \mathrm{ppm}$ \\
\hline Total $\mathrm{Mn}(\mathrm{ppm})$ & $12 \mathrm{ppm}$ \\
\hline Total $\mathrm{Zn}(\mathrm{ppm})$ & $7 \mathrm{ppm}$ \\
\hline Total $\mathrm{Cu}(\mathrm{ppm})$ & $5 \mathrm{ppm}$ \\
\hline
\end{tabular}


The application method and date of humic acid

Humic acid was added as a soil application to the wetted compost in solution which was prepared by dissolving $50 \mathrm{ml}$ of the commercial compound "Actosol" $(2.9 \%$ humic acid $+10-10-10 \%$ NPK $)$ in 1 liter of tap water. The addition of humic acid solution was carried out every other week starting from fruit set till September at the rate of one litter (which previously have already been prepared) per tree in both seasons of study.

The application method of chemical fertilizers

Two rates of chemical fertilizers NPK were employed in this study. The first rate was $100 \%$ of NPK $(450,100$, and $500 \mathrm{~g}$ of N, P and K per tree, respectively) which regularly used as a chemical fertilizer program recommended by the Ministry of Agriculture. The second rate was $50 \%$ of NPK $(225,50$ and $250 \mathrm{~g}$ of $\mathrm{N}, \mathrm{P}$ and $\mathrm{K}$ per tree, respectively). The chemical fertilizers were added in two equal doses at the first week of February and two weeks later of fruit set through drip irrigation system during both seasons of study. Ammonium nitrate $\left(\mathrm{NH}_{4} \mathrm{NO}_{3}, 33.5 \% \mathrm{~N}\right)$, mono Calcium phosphate $\left(15.5 \% \mathrm{P}_{2} \mathrm{O}_{5}\right)$ and potassium sulphate $\left(\mathrm{K}_{2} \mathrm{SO}_{4}\right.$ - high soluble $\left.50 \% \mathrm{~K}_{2} \mathrm{O}\right)$ were used as a source of $\mathrm{N}, \mathrm{P}$ and $\mathrm{K}$ respectively.

The investigated materials including organic manure (compost), bio-fertilizers (Phosphorene, Nitropene, Potassien and EM), humic acid, organic compost tea and NPK mineral fertilizers were arranged and designed in different combinations in order to build up the following skeleton investigated treatments:

T1. NPK $100 \%$

T2. Compost $100 \%$

T3. Compost $100 \%+\mathrm{EM}$

T4. Compost $100 \%+$ bio-fertilizer

T5. Compost $100 \%+$ Humic acid

T6. Compost $100 \%+$ Compost tea

T7. Compost $100 \%+$ EM+ bio-fertilizer + Humic acid + Compost tea

T8. NPK $50 \%+$ Compost $50 \%$

T9. NPK $50 \%+$ Compost $50 \%+$ EM

T10. NPK $50 \%+$ Compost 50\% + Bio-fertilizer

T11. NPK $50 \%+$ Compost $50 \%+$ Humic acid

T12. NPK $50 \%+$ Compost $50 \%+$ Compost tea

T13. NPK $50 \%+$ Compost 50\% + EM + Bio-fertilizer + Humic acid + Compost tea

Complete randomized block design was used for arranging the thirteen abovementioned soil fertilization treatments, whereas each treatment was replicated four times and each replicate represented by one individual apricot fruit tree.

Methodology which has been followed in this study is being determined as follows:

Egypt. J. Hort. Vol. 42, No.1 (2015) 


\section{Vegetative measurements}

The increment percentage in trunk diameter (ITD \%)

Trunk circumference for each individual tree was measured twice at height about $20 \mathrm{~cm}$ from the trunk base. The first (initial) measurement was done before fertilizer addition, while the second one (final) was preformed at the end of the growing season (mid- November). The increment percentage of trunk diameter (ITD) was calculated according to the following equation:

$$
\mathrm{ITD}=\frac{\text { Final trunk circumference }- \text { initial trunk circumference }}{\text { Initial trunk circumference }} \times 100
$$

Average length and thickness of new shoots (cm)

Both shoot length and circumference in $(\mathrm{cm})$ for 40 shoots per each individual tree (10 from every direction/labeled limb) were determined then the average of both parameters was calculated when the length was ceased in the last week of August during each experimental season.

\section{Average number of leaves per shoot}

Total number of leaves which were developed on the forty tagged shoots per individual tree (replicate) was counted and recorded in the last week of August, and then the average number of leaves per shoot was estimated.

Leaf area and its dry weight

On late August during both seasons of study, samples of thirty mature leaves were collected by picking up the third to the fifth one from the base of the previously labeled shoots, and then leaf area was measured by using the planimeter. These leaves were wiped with a damp cloth to eliminate dust, then oven dried at $70^{\circ} \mathrm{C}$ till constant weight, and then leaf dry weight in $\mathrm{mg}$ was recorded.

\section{Nutritional status (leaf chemical composition)}

Leaf mineral contents

Leaf nutrient contents (macro and micro elements) were determined in the oven dried leaf samples (4- $6^{\text {th }}$ leaf from the base) which were collected at last week of August. Leaves were taken as previously described, dried at $70^{\circ} \mathrm{C}$ until constant weight, then used for the following analysis:

\section{a. Total nitrogen}

Total nitrogen content of dried leaves samples was determined by the modified micro-Kjeldahl method as described by Pregl (1945).

\section{b. Total phosphorus}

Total leaf phosphorus content was determined using a Spekol spectrophotometer at $882.0 \mathrm{UV}$ according to the method described by Murphy and Riely (1962). 
c. Leaf $\mathrm{K}, \mathrm{Ca}, \mathrm{Mg}, \mathrm{Fe}, \mathrm{Zn}$ and $\mathrm{Mn}$ contents were determined by using the Atomic Absorption Spectrophotometer (3300) according to Jackson and Ulrich (1959) and Chapman and Pratt (1961).

Leaf nutrient elements contents were expressed as a ratio of the leaf dry weight, i.e., percentage for the macro-elements $(\mathrm{N}, \mathrm{P}, \mathrm{K}, \mathrm{Ca}$ and $\mathrm{Mg}$ ) and part per million (ppm) with micro-nutrient elements ( $\mathrm{Fe}, \mathrm{Zn}$ and $\mathrm{Mn})$.

\section{Leaf photosynthetic pigments content}

Representative fresh leaf samples of the same physiological age and position (at the $4-6^{\text {th }}$ leaf from the base) were taken at mid August and photosynthetic pigments (chlorophyll a, b and carotein) were coloremetrically determined according to Mackinney (1941).

\section{Statistical analysis}

All the obtained data in the two seasons of study were statistically analyzed using the analysis of variance method according to Snedecor and Cochran (1980). However, means were distinguished by the Duncan's multiple range test (Duncan, 1955).

\section{Results and Discussion}

Vegetative growth measurements

Increment (\%) in trunk diameter

Regarding the increment \% in trunk diameter of apricot trees "Canino" cv. as affected by inorganic, organic fertilizer and some soil stimulants, data tabulated in Table 5 revealed obviously that the investigated parameter was significantly affected by the different treatments. However, the highest significant values $(19.67 \%$ and $22.20 \%)$ of trunk diameter increment were achieved when the trees were fertilized with inorganic (NPK) fertilizer at $100 \%$ level (the recommend dose $-\mathrm{T} 1)$ in the $1^{\text {st }}$ and the $2^{\text {nd }}$ season, respectively as well as the trees which were received NPK at $50 \%+$ organic (compost) at $50 \%+\mathrm{EM}+$ bio-fertilizers + humic acid (HA) + compost tea (T13) gave the highest trunk diameter increment $\%$ in the $2^{\text {nd }}$ season only as compared with the other investigated treatments.

On the other hand, the least values $(12.40 \%$ and $17.27 \%)$ of trunk diameter increment $\%$ were detected with those trees which were received organic (compost) fertilizer at $100 \%$ level (T2) during both seasons of study.

This result go in line with those reported by Bussi and Amiot (1998) they indicated that fertilization of apricot trees with mineral nitrogen fertilizers significantly increased trunk circumference and there was a linear correlation between growth rate and dose of application. Like wise, persimmon trees "Costata" cv. which were fertilized with both organic and bio-fertilizers significantly induced the highest values of trunk circumference increase \% (Darwiesh, 2012).

Egypt. J. Hort. Vol. 42, No.1 (2015) 
Average shoot length $(\mathrm{cm})$

With regard to the response of average shoot length $(\mathrm{cm})$ of apricot trees "Canino" cv. as affected by inorganic (NPK), organic (compost) fertilizers and some soil stimulants, data presented in Table 5 indicated significantly effect by the various investigated treatments. Moreover, the apricot trees which were fertilized by (T1) or (T13) reflected the highest significant values of shoot length $(38.34 \mathrm{~cm}$ and $40.10 \mathrm{~cm})$ and $(37.83 \mathrm{~cm}$ and $39.23 \mathrm{~cm})$ in the $1^{\text {st }}$ and the $2^{\text {nd }}$ season, respectively, Meanwhile, the fertilization with inorganic (NPK) fertilizer at $50 \%$ level + organic (compost) fertilizer at 50\% level combined with one or more of soil stimulants were better than the corresponding treatments that including organic fertilizer at $100 \%$ level in enhancing the investigated parameter during both seasons of study.

On the other hand, the reverse was true with those trees which were fertilized with organic (compost) fertilizer at $100 \%$ level alone, whereas those reflected the least values of average shoot length during both seasons of study.

\section{Shoot diameter $(\mathrm{cm})$}

Concerning shoot diameter of apricot trees "Canino" cv. as affected by inorganic (NPK), organic (compost) fertilizers and some soil stimulants, data presented in Table 5 revealed that shoot diameter appeared to be affected significantly by the different tested treatments. Herein, the trees which were fertilized with either (T1) or (T13) had the highest values of shoot diameter during both seasons of study. Meanwhile, the fertilization with inorganic (NPK) and organic (compost) fertilizers together each at 50\% level combined with one or all soil stimulants were more effective in enhancing shoot diameter than the fertilization with organic (compost) fertilizer combined with the corresponding stimulators during both seasons of study.

On the other hand, the reverse was true when the trees were received organic (compost) fertilizer at $100 \%$ level (T2), whereas such treatment gave the least value of shoot diameter during both seasons.

\section{Average number of leaves/ shoot}

Regarding the effect of inorganic (NPK), organic (compost) fertilizers and some soil stimulants on average number of leaves/ shoot of apricot trees "Canino" cv., data tabulated in Table 6 clearly indicated that all the investigated treatments significantly affected the average number of leaves/ shoot. Hence, fertilizer addition in the form of inorganic (NPK) at 100\% level (recommended dose - T1) was the best investigated treatment in this respect whereas it significantly maximized the average number of leaves/ shoot during both seasons of study. Meanwhile, the fertilization with inorganic (NPK) at 50\% level + organic (compost) fertilizer at 50\% level including all investigated soil stimulants came in the second rank in this respect. 


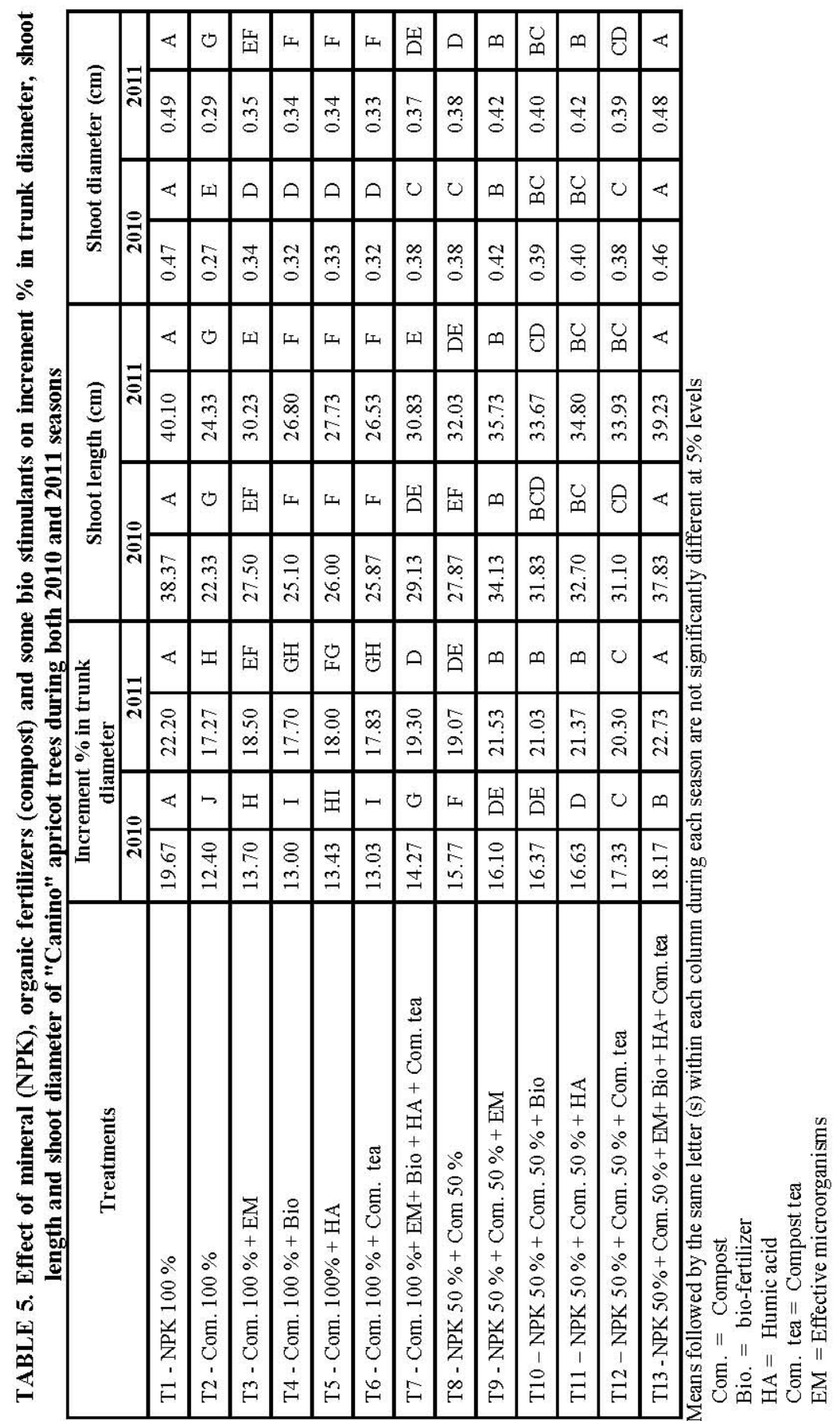

Egypt. J. Hort. Vol. 42, No.1 (2015) 
On the other hand, the least value of average number of leaves/ shoot was detected with apricot trees which were fertilized with organic (compost) fertilizer at $100 \%$ level (T2) and were completely deprived of inorganic (NPK) fertilizer. Such trend was true during both seasons.

Average leaf area $\left(\mathrm{cm}^{2}\right)$

With regard to average leaf area $\left(\mathrm{cm}^{2}\right)$, data presented in Table 6 obviously cleared that there were significant differences among the investigated treatments. Likewise, the highest value of average leaf area was always concomitant to those apricot trees which were fertilized with either (T1) solely or sharing the organic (compost) fertilizer by $50 \%$ with inorganic (NPK) by $50 \%$ combined with all investigated soil stimulants (T13) during both seasons of study. Meanwhile, the sharing between the inorganic (NPK) and organic (compost) fertilizers by $50 \%$ for each the greater of average leaf area was likely to be. Otherwise, the addition of fertilizer in the form of organic (compost) associated with either one or all soil stimulants were less effective in this respect.

On the other way around, the reverse was true with those trees which were received organic (compost) fertilizer at $100 \%$ level (T2), whereas it recorded the least value of average Leaf area during both seasons of study.

Leaf dry weight ( $m g)$

Regarding the effect of inorganic (NPK), organic (compost) fertilizer and some soil stimulants on leaf dry weight of apricot trees "Canino" cv., data tabulated in Table 6 indicated that there were significant differences among the tested treatments. Meanwhile, the (T1) and (T13) were the superior treatments, whereas both were paralleled to each other and achieved the highest value of leaf dry weight i.e., both gave the heaviest leaf dry weight during both seasons.

On the other way around, the (T2) recorded the least value of leaf dry weight during both study seasons.

These results are in agreement with those reported by Bussi et al. (2003) on apricot "Bergeron" cv., Shaddad et al. (2005) on "Canino" cv. and Rettke et al. (2006) on "Moorpark" cv. They reported that all vegetative growth measurements (shoot length, shoot diameter, number of leaves per shoot and leaf area) were increased with increasing the mineral fertilizer rates. The most effective fertilization rate was found to be $96-64-256 \mathrm{~kg}$ NPK/ha (Asma et al., 2007).

Regarding the effect of chemical, organic and bio- fertilizers on vegetative growth parameters (shoot length, number of leaves per shoot, leaf area, shoot thickness and trunk diameter) of apricot trees, Kabeel et al. (2005) reported that bio- fertilizers had a positive effect on the growth of "Canino" cv. Meanwhile, biofertilizers combined with compost at $100 \%$ level were the superior treatment in inducing the vegetative growth of Canino" cv. El-Naggar (2009). In addition, Stino et al. (2009) reported that mineral fertilization significantly improved the vegetative growth parameters of Canino" cv. as compared with organic fertilization (compost) either alone or in combination with the bio- fertilizers. 


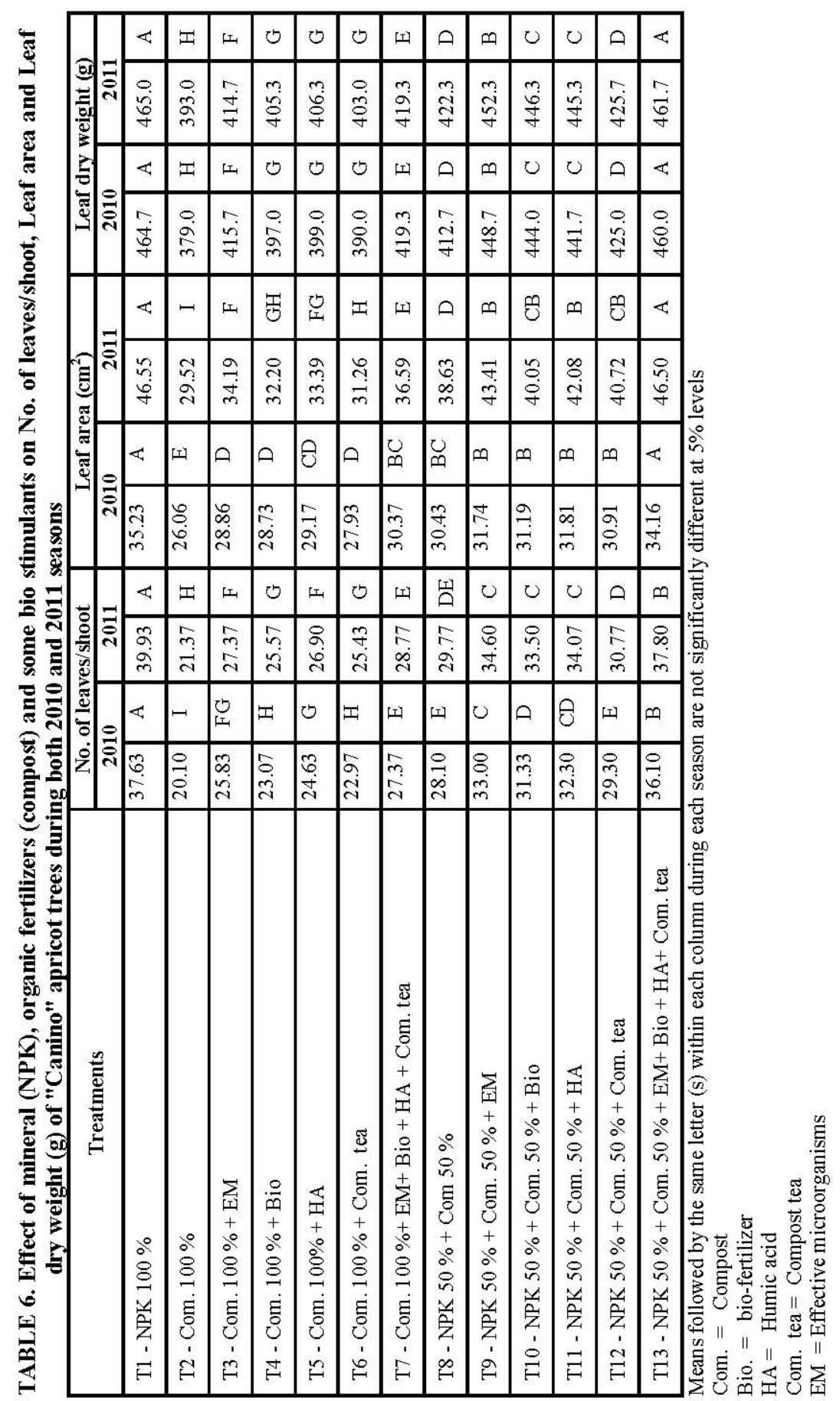

Egypt. J. Hort. Vol. 42, No.1 (2015) 


\section{Leaf macro and micro elements content}

Leaf nitrogen content (\%)

Regarding leaf nitrogen content (\%) of apricot "Canino" cv., data presented in Table 7 showed that leaf nitrogen content was significantly affected by different tested treatments during both seasons of study. Herein, both (T1) and (T13) significantly achieved the highest values of leaf nitrogen content, whereas both treatments recorded $(2.76 \%$ and $2.81 \%)$ and $(2.71 \%$ and $2.78 \%)$ in the in the $1^{\text {st }}$ and $2^{\text {nd }}$ season, respectively.

On the other hand, the least values $(2.04 \%$ and $2.1 \%)$ ) in the $1^{\text {st }}$ and the $2^{\text {nd }}$ season, respectively of leaf nitrogen content were detected when the trees were received sole organic (compost) fertilizer at $100 \%$ level (T2).

\section{Leaf phosphorus content (\%)}

With respect to leaf phosphorus content, data tabulated in Table 7 obviously revealed that there were significant differences among the tested treatments. Hence, the trees which were fertilized with mineral (NPK) fertilizer (T1) showed the highest values $(0.31 \%$ and $0.31 \%)$ of leaf phosphorus content during the $1^{\text {st }}$ and $2^{\text {nd }}$ season, respectively, as will as the fertilization with mineral (NPK) and organic (compost) fertilizer each at $50 \%$ level combined with all soil stimulants (T13) achieved result imaged to (T1), whereas it reflected $(0.30 \%$ and $0.30 \%)$ in the $1^{\text {st }}$ and $2^{\text {nd }}$ season, respectively, it was remarkable that compost tea addition to NPK in mineral form at $50 \%$ level + organic (compost) at $50 \%$ level (T12) had little effect in this respect.

On the other hand, the least value of leaf phosphorus content was observed when the trees were fertilized with sole organic fertilizer (compost) at 100\% level (T2).

\section{Leaf potassium content (\%)}

Data presented in Table 7 dealing with leaf potassium content of apricot "Canino" cv., revealed that $\mathrm{K}$ in the leaf was significantly affected by all treatments, whereas the (T1) as well as (T13) were the superior ones in this respect. Both treatments ( $\mathrm{T} 1$ and $\mathrm{T} 13)$ achieved the highest values $(2.59 \%$ and $2.56 \%$ ) of leaf potassium content in the $2^{\text {nd }}$ season, while (T1) recorded the highest value $(2.55 \%)$ of leaf potassium content in the $1^{\text {st }}$ season, meanwhile (T13) came in the second rank in the $1^{\text {st }}$ season.

On the other way around, the trees which treated with (T2) were the inferior one in this respect, whereas it gave the least value of potassium in leaf.

\section{Leaf calcium content (\%)}

Data presented in Table 8 revealed that leaf calcium content was significantly affected by all tested treatments. Herein, NPK chemical (inorganic) fertilizer (T1) as well as fertilizer mixtures (T13) significantly maximized leaf calcium content during both seasons. Meanwhile, the fertilizer mixture (EM-T9) or (bio-fertilizer $-\mathrm{T} 10$ ) or (humic acid - T11) had also the highest value of leaf calcium content in the $2^{\text {nd }}$ season only. 


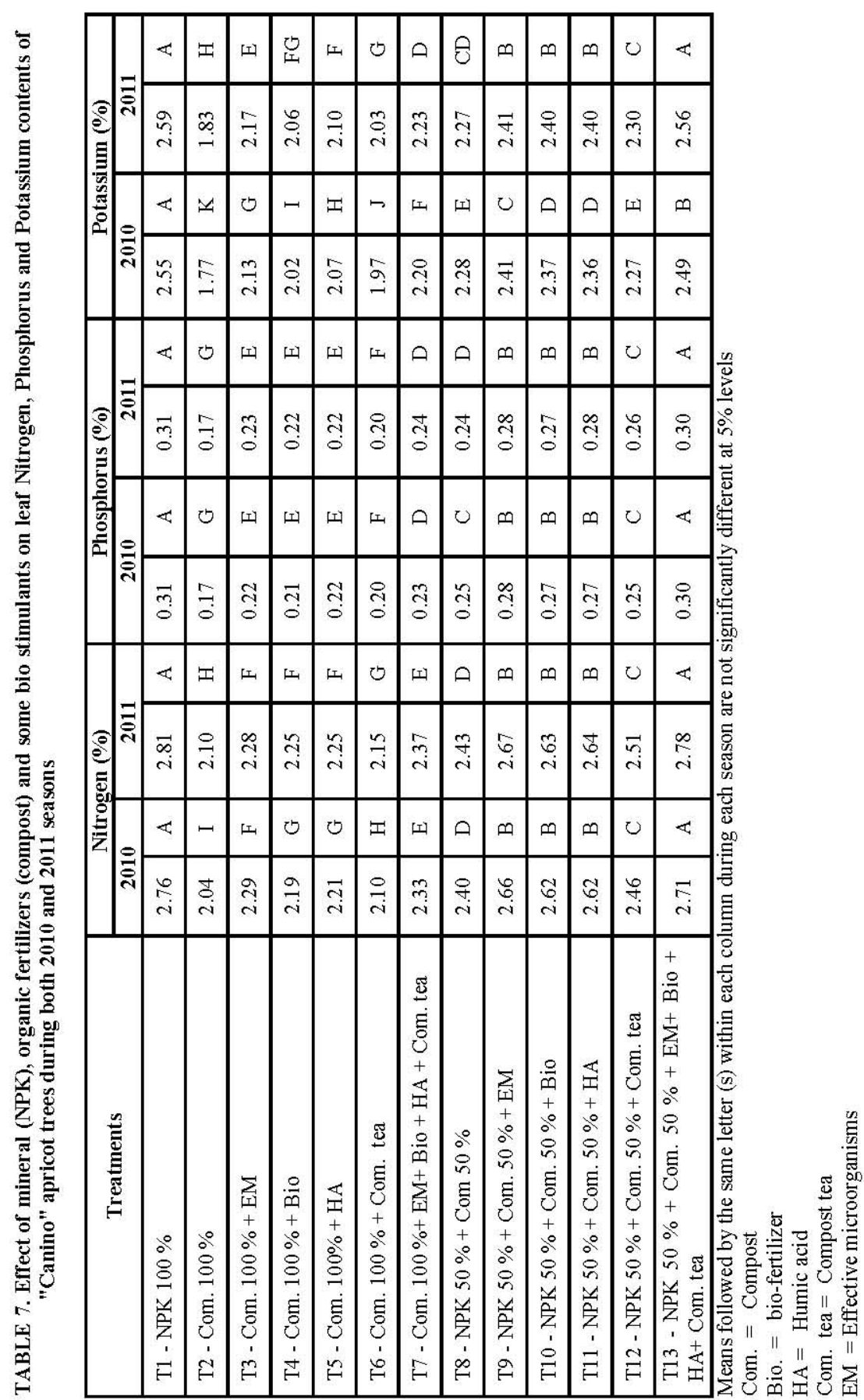

Egypt. J. Hort. Vol. 42, No.1 (2015) 
PHYSIOLOGICAL STUDIES ON APRICOT TREES ...

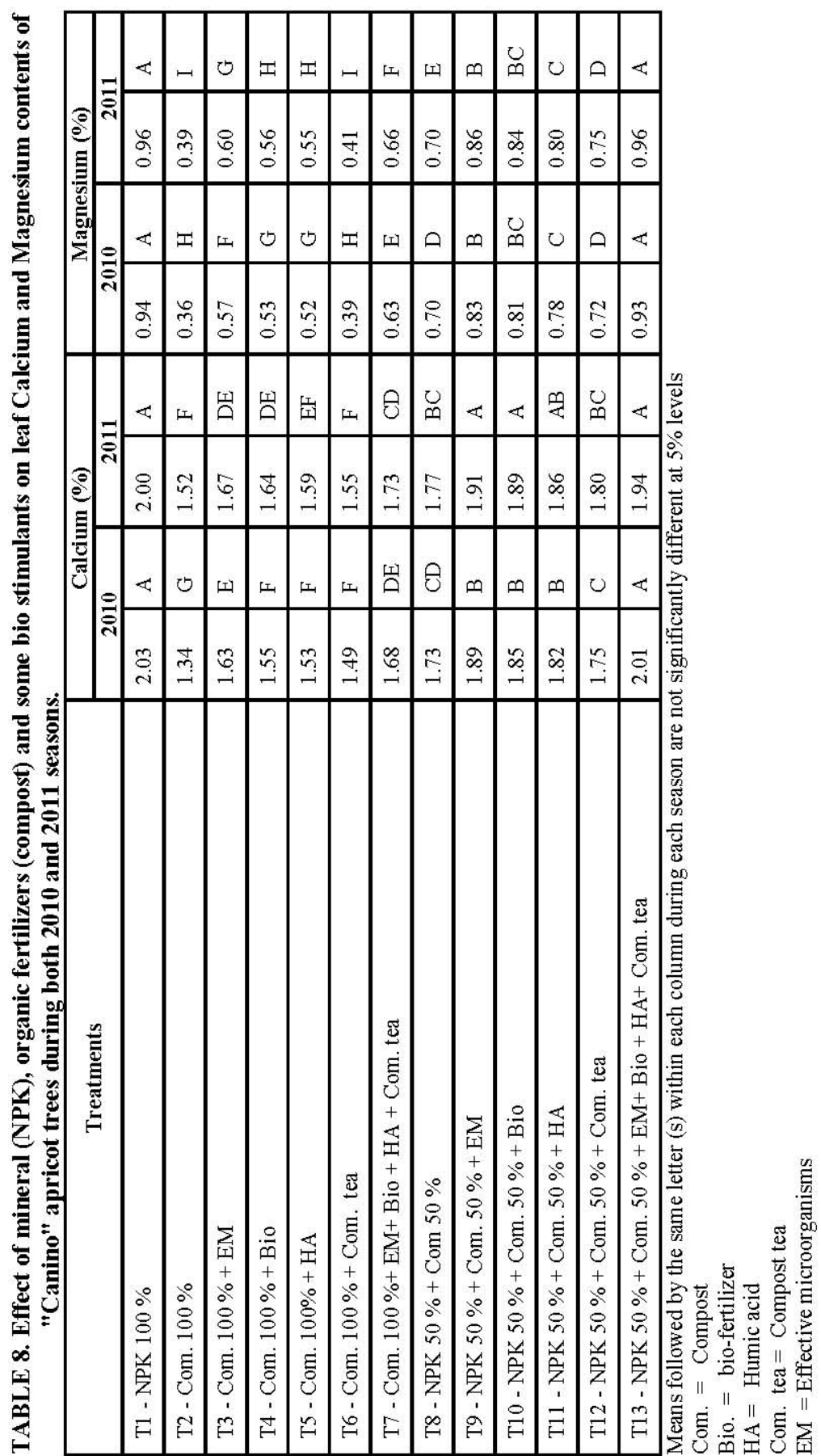

Egypt. J. Hort. Vol. 42, No.1 (2015) 
On the other hand, trees which fertilized with sole organic (compost) fertilizer (T2) significantly showed the least value of leaf calcium content. Such trend was true during both study seasons.

\section{Leaf magnesium content (\%)}

Data presented in Table 8 clearly reflected that leaf magnesium content of apricot "Canino" cv. was significantly affected by different tested treatments. The fertilization with (T1) as well as the fertilization with (T13) was the superior ones in this respect, whereas both treatments led to achieve the highest values $(0.94 \%$ and $0.96 \%)$ and $(0.93 \%$ and $0.96 \%)$ of leaf magnesium content in the $1^{\text {st }}$ and the $2^{\text {nd }}$ season, respectively. Meanwhile, the fertilization with inorganic (mineral) form combined with organic (compost) form fertilizer was more effective in this respect than using organic (compost) fertilizer alone. Such trend was true during both seasons of study. However, the effect of EM stimulator was more pronounced than that remarked with the other stimulants. Compost tea stimulator was the inferior one in this respect, and subsequently the fertilization with organic (compost) fertilizer alone at $100 \%$ level (T2) or combined with compost tea (T6) recorded the least values of the investigated parameter during both seasons of study.

\section{Leaf iron content (ppm)}

Concerning leaf iron content of apricot "Canino" cv., data presented in Table 9 obviously revealed that leaf iron content was significantly affected by the different investigated treatments. In this respect, the fertilization with (T13) was the best treatment in this respect, whereas it gained the highest values (105.1 ppm and 108 $\mathrm{ppm}$ ) of leaf iron content during the $1^{\text {st }}$ and $2^{\text {nd }}$ season, respectively. On the other hand, the least values ( $57 \mathrm{ppm}$ and $60.9 \mathrm{ppm})$ of leaf iron content in the $1^{\text {st }}$ and $2^{\text {nd }}$ season, respectively were reported when the trees were fertilized with (T2).

\section{Leaf zinc content (ppm)}

Data tabulated in Table 9 indicated that there were significant differences among the tested treatments in relation to zinc in leaf of apricot trees "Canino" $\mathrm{cv}$. The fertilization with (T13) was the best treatment in this respect, whereas it significantly maximized the values $(23.14 \mathrm{ppm}$ and $24.08 \mathrm{ppm})$ of leaf $\mathrm{Zn}$ content in the $1^{\text {st }}$ and $2^{\text {nd }}$ season, respectively.

On the other hand, the reverse was true when the trees were fertilized with (T2), whereas it gave the least value of leaf Zinc content during both seasons.

\section{Leaf manganese content (ppm)}

Regarding leaf manganese content of apricot trees "Canino" cv., data presented in Table 9 obviously indicated that the investigated parameter was significantly affected by different treatments in both seasons of study. Furthermore, the fertilization with (T1) or (T13) were the dominant one in this respect, whereas both treatments significantly achieved the highest values of leaf manganese content during both seasons.

Egypt. J. Hort. Vol. 42, No.1 (2015) 


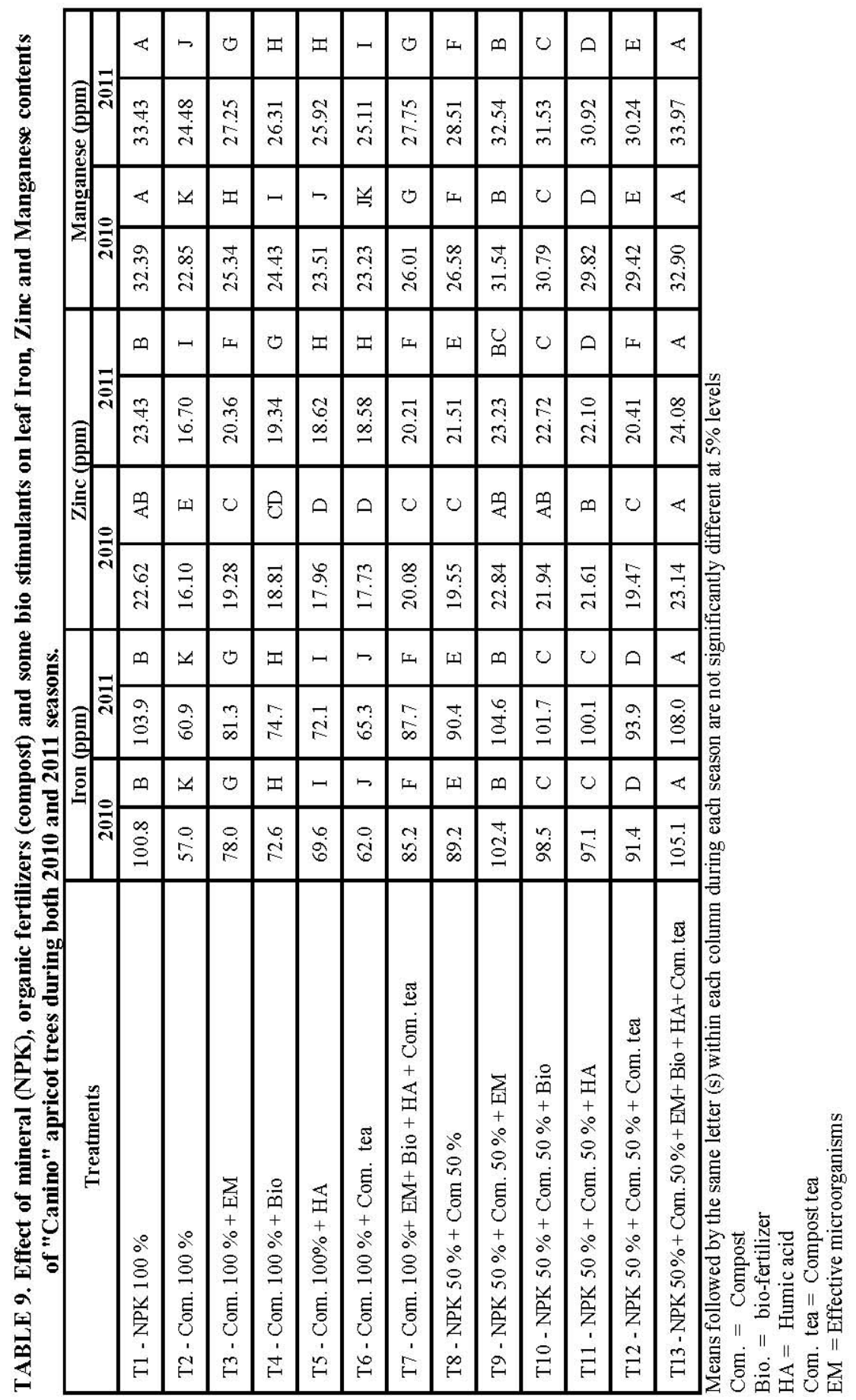




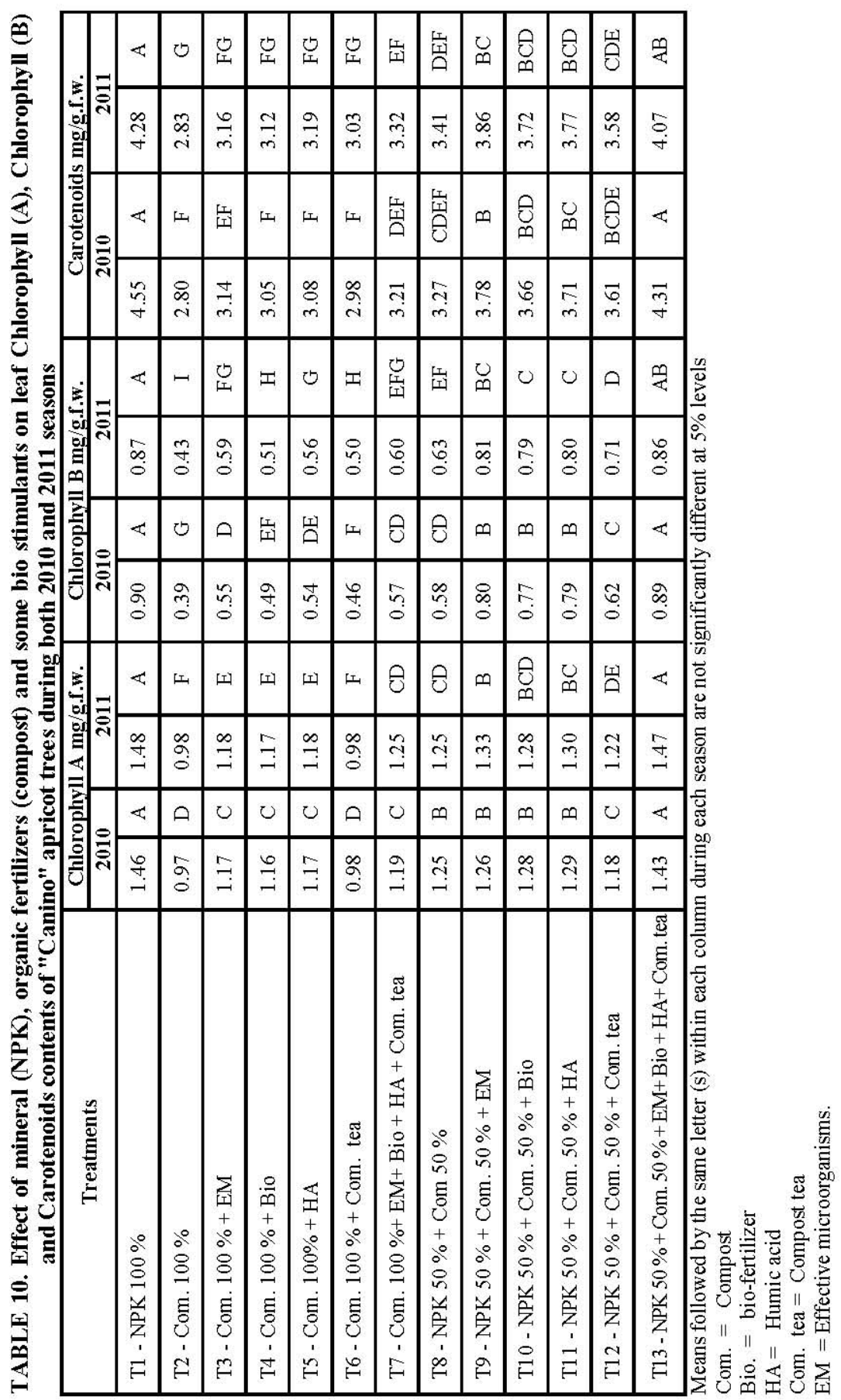

Egypt. J. Hort. Vol. 42, No.1 (2015) 
On the other hand, the least value of leaf manganese content was detected in trees which were fertilized with sole organic (compost) fertilizer at $100 \%$ level (T2). Such trend was true during both seasons.

The obtained results regarding leaf macro and micro nutrient contents of apricot trees "Canino" cv. were supported by the findings of many investigators. Joolka et al. (1990) reported that apricot trees received $\mathrm{N}$ as basal dressing led to increase leaf $\mathrm{N}, \mathrm{Ca}, \mathrm{Mg}$ and $\mathrm{Fe}$ content. Soil mineral and bio-fertilizers application (NK, Nitrobien, Phosphorene and Enciabein) resulted in a significant increase in apricot leaf content of N, P and K (Kabeel et al., 2005). Meanwhile, Shaddad et al. (2005) reported that bio-fertilizers exhibited increase in some apricot leaf mineral content $(\mathrm{N}, \mathrm{P}$ and $\mathrm{K})$. The greatest values of apricot leaf $(\mathrm{N}$, $\mathrm{P}, \mathrm{K}, \mathrm{Ca}, \mathrm{Mg}, \mathrm{Zn}, \mathrm{Fe}$ and $\mathrm{Mn}$ ) content were recorded with those trees fertilized with the highest level of NK combined with bio-fertilizers (El- Naggar, 2009). Stino et al. (2009) demonstrated that high levels of organic fertilizer (at 100 or $150 \%$ of compost) combined with bio-fertilizers increase leaf mineral (N, P, K, $\mathrm{Ca}, \mathrm{Mg}, \mathrm{Zn}, \mathrm{Fe}$ and $\mathrm{Mn}$ ) content of young "Canino" apricot trees.

\section{Leaf photosynthetic pigments}

Data presented in Table 10 cleared that leaf content of photosynthetic pigments was significantly affected by the treatments under study. However, the fertilization with (T1) or (T13) significantly showed the highest values of the three investigated parameters (chlorophyll a, b and carotienoides). Such trend was true during both seasons.

On the other hand, the least value of leaf chlorophyll b content was observed when the trees were fertilized with (T2). Moreover, leaf chlorophyll a content was significantly minimized with either (T2) or the same treatment included compost tea (T6). Neither (T2) nor the same treatment combined with either of the stimulants (EM - T3), (bio-fertilizer - T4), (humic acid - T5) was able to enhance the leaf carotenoids content, but the reverse was true, whereas all gave the minimum value of that tested character. Such trend was true during both seasons.

These results are in harmony with those found by Shaddad et al. (2005) who showed that Canino apricot leaves contained more N, P, and $\mathrm{K}$ as a result of soil application of humic acid which pressed the leaves to gain more chlorophyll and more dry matter. In addition, bio-fertilization increases leaf chlorophyll content of "Canino" apricot (Ibrahim et al., 2005). On Red - peach trees, organic manure + bio-fertilizer improved leaf pigments compared with the same organic fertilizer alone, while the chemical fertilizer produced the highest leaf pigments content (Fayed, 2005a). Meanwhile, Mohamed et al. (2010) reported that application of compost with bio-fertilizers + humic acid + compost tea gave a better effect on leaf pigments content of "Le- Conte" pear trees. 
It could be concluded that the fertilization with NPK at $50 \%+$ organic (compost) at $50 \%+\mathrm{EM}+$ bio-fertilizers + humic acid (HA) + compost tea were the most effective treatments for increasing vegetative growth parameters and leaf nutrient contents of "Canino" cv. Apricot trees.

\section{References}

Abou Hussein, S.D., El-Oksha, I., El-Shorbagy, T. and Gomaa, A.M. (2002) Effect of cattle manure, bio fertilizers and reducing mineral fertilizer on nutrient content and yield of potato plant. Egypt. J. Hort., 29 (1), 99-115.

Asma, B.M., Colak, S., Akca, Y. and Genc, C. (2007) Effect of fertilizer rate on the growth, yield and fruit characteristics of dried apricot (cv. Hacihaliloglu). Asian J. Plant Sci., 6 (2), 294-297.

Bussi, C. and Amiot, M.J. (1998) Effects of nitrogen and potassium fertilization on the growth, yiled and pit burn of apricot (cv. Bergeron). J. Hort. Sci. and Biotech., 73 (3), 387-392.

Bussi, C., Besset, J. and Girard, T. (2003) Effects of fertilizer rates and dates of application on apricot (cv. Bergeron). Cropping and Pitburn. Scientia Horticulture, 98 (2), 139-147.

Chapman, H.D. and Pratt, P.F. (1961) Methods of Analysis for Soil, Plant and Waters, $6^{\text {th }}$ ed. Univ. of Calif., Division of Agric. Sc., pp. 56-64.

Darwiesh, D.R.A. (2012) Physiological studies on persimmon "diospyros kaki" trees. Ph.D. Thesis, Fac. Agric., Benha. Univ.

Duncan, D.B. (1955) Multiple ranges and multiple F. test. Biometrics, 11, 1-42.

El-Naggar, Y.I. (2009) Physiological studies on fertilization of young apricot trees "Canino" cultivar. Ph.D. Thesis, Fac. of Agric. Moshtohor, Benha Univ., Egypt.

Fathi, M.A., Fawzia- Eissa, M. and Yehia, M.M. (2002) Improving growth, yield and fruit quality of "Desert Red" peach and "Anna" apple by using some bio-stimulants. Minia J. Agric. Res. \& Dev., 22 (4), 519-534.

Fawzia- Eissa, M., Faith, M.A. and El-Shall, S.A. (2007) Response of peach and apricot seedlings to humic acid treatments under salinity condition. J. Agric. Sci. Mansoura Univ., 32 (5), 3605-3620.

Fayed, T.A. (2005a) Response of Desert Red peach trees to organic and some bio fertilizers in comparison with chemical fertilizers. A- Growth and nutritional status. Egypt. J. Appl. Sci., 20 (1), 127-143.

Egypt. J. Hort. Vol. 42, No.1 (2015) 
Fayed, T.A. (2005b) Effect of some organic manures and bio-fertilizers on Anna apple trees. A-vegetative growth and leaf chemical constituents. Egypt. J. Appl. Sci., 20 (1), 159 -175.

Hassan, H.S.A. and Abou-Rayya, M.S. (2003) Effect of some bio fertilizers on leaf mineral content, yield and fruit quality of Anna apple trees grown under Northern Sinai condition. Egypt. J. Appl. Sci., 18 (8B), 559-574.

Higa, T. (2000) What is EM technology? EM World J., 1, 1-6.

Hussain, T., Anjum, A.D. and Tahir, J. (2002) Technology of beneficial microorganisms. Nature Farm Environ., 3, 1-14.

Ibrahim, H.K., Abd El-Atif, G.S. and Khalil, A.A. (2005) Effect of soil application of different treatments on growth, fruiting parameters, fruit properties and leaf nutrients content of Canino apricot trees. J. Agric. Sci. Mansoura Univ., 30(3) 1617-1629.

Ingham, E. (2005) The compost tea brewing manual as printings. Soil Food Web Incorporated, Vegan, 3, 31-32.

Jackson, M.L. and Ulrish, A. (1959) Analytical Methods for Use in Plant Analysis, Coll. of Agric. Exp. State Bull. 766, 35.

Jackson, M.L. (1967) "Soil Chemical Analysis", Prentice-Hall. Inc. Englewood Clif., N, I. Library Congress, U.S.A.

Joolka, N.K., Chandel, C.K. and Bhutani, V.P. (1990) Effect of N, P and Agromin on the leaf mineral composition of "New Castle" apricot. Haryana J. of Hort. Sci., 19 (1-2), 50-54.

Kabeel, H., Abd El-Latif, G.S. and Khalil, A.A. (2005) Effect of soil application of different mineral and bio-fertilizer treatments on growth, fruiting parameters, fruit properties and leaf nutrient content of "Canino" apricot trees. J. Agric. Sci. Mansoura Univ., 30 (3), 1583-1594.

Mackinney, G. (1941) Absorption of light by chlorophyll solutions. J. Biochem., 140, 315-322.

Mansour, A.E.M. (1998) Response of Anna apple to some bio-fertilizers. Egypt. J. Hort., 25 (2), 241-251.

Mohamed, S.M., Fayed, T.A., Ismail, A.F. and Abdou, N.A. (2010) Growth, nutrient status and yield of le-conte pear trees as influenced by some organic and biofertilizer rates compared with chemical fertilizer. Bull. Fac. Agric. Cairo Univ., 61, 17-32.

Murphy, J. and Riely, J.P. (1962) A modified single method for the determination of phosphorus in natural water. Anal. Chem. Acta., 27, 31-36.

Egypt. J. Hort. Vol. 42, No.1 (2015) 
Piper, C.S. (1947) "Soil and Plant Analysis", Inter. Sci. Publishers. New York, 213-217.

Pregl, E. (1945) "Quantitative Organic Micro Analysis". $4^{\text {th }}$ ed., Chundril, London.

Rettke, M.A., Pitt, T.R., Maier, N.A. and Jones, J.A. (2006) Growth and yield responses of apricot (cv. Moorpark) to soil-applied nitrogen. Australian J. of Experimental Agric., 46 (1), 115-122.

Shddad, G., Khalil, A. and Fathi, M.A. (2005) Improving growth, yield and fruit quality of "Canino" apricot by using bio, mineral and humate fertilizers. Minufiya J. Agric. Res., 30 (1), 317-328.

Snedecor, G.W. and Cochran, W.G. (1980) "Statistical Methods", $7^{\text {th }}$ ed., Oxford and J.B.H. publishing com. 593 p.

Stino, R.G., Mohsen, A.T., Maksoud, M.A., El-Migeed, M.M., Gomaa, A.M. and Ibrahim, A.Y. (2009) Bio-organic fertilization and its impact on apricot young trees in newly reclaimed soil. American -Eurasian Journal of Agricultural and Environmental Science, 6 (1), 62-69.

Zhou, X.W., Li, Z.Y., Lu, B., Chen, X.N. and Yi, Y.W. (2001) Study on the improvement of soil of the newly established orchard on the reclaimed purple soil. $J$. Fruit Sci., 18 (1), 15-19.

(Received 9/9/2014;

accepted $11 / 1 / 2015)$ 

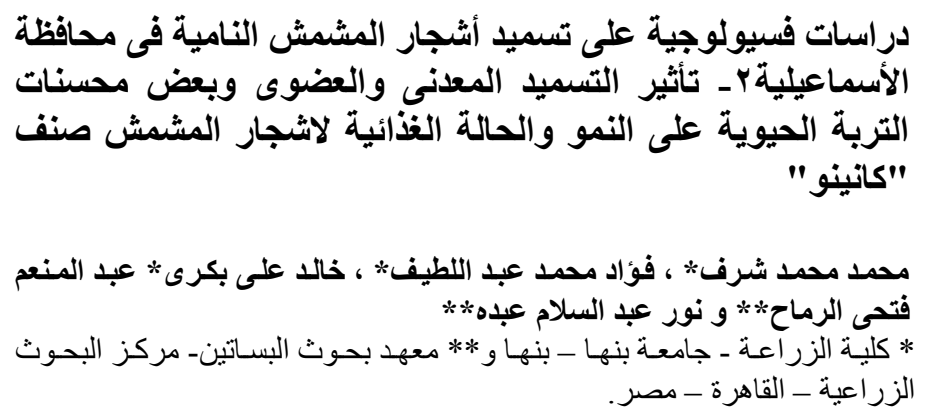

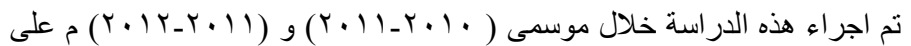

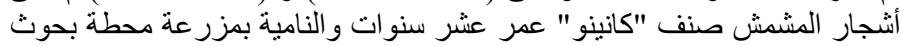

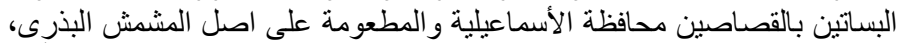

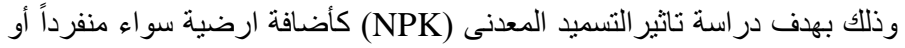

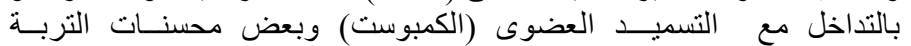

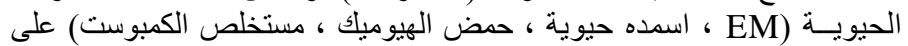

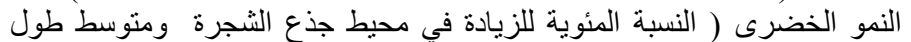

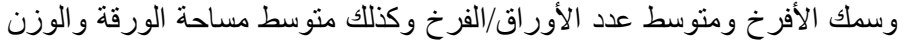

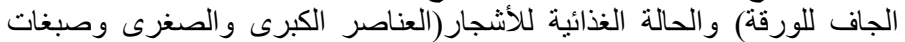
التمثيل الضوئي).

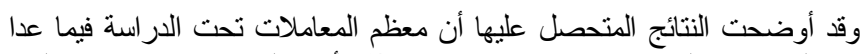

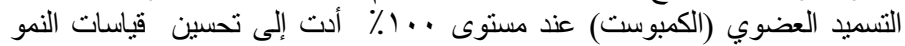

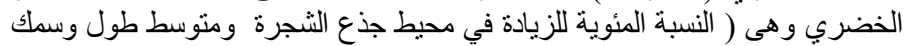

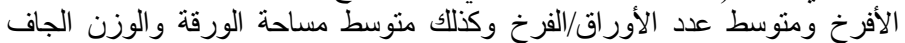

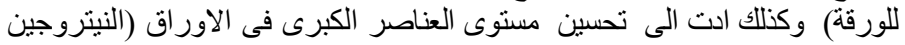

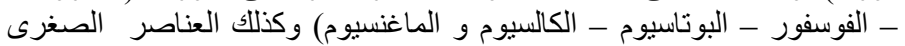

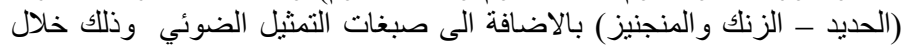

$$
\text { موسمى الدر اسة. }
$$

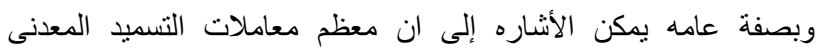

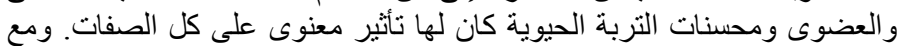

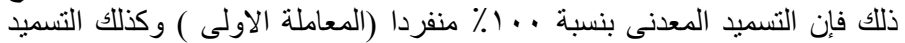

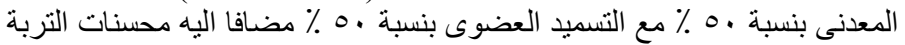

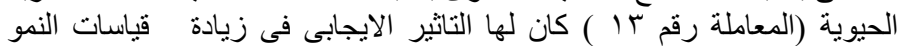

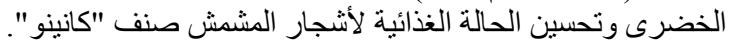

